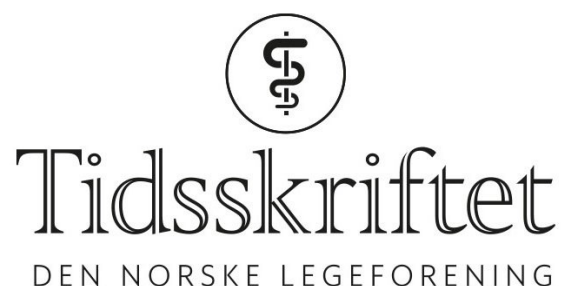

\title{
Inn i fremtiden med 3D og hologram
}

MITT FAGFELT

Anders Haugom Christensen er spesialist i barnesykdommer og fellow ved Barnekardiologisk avdeling på Rikshospitalet.

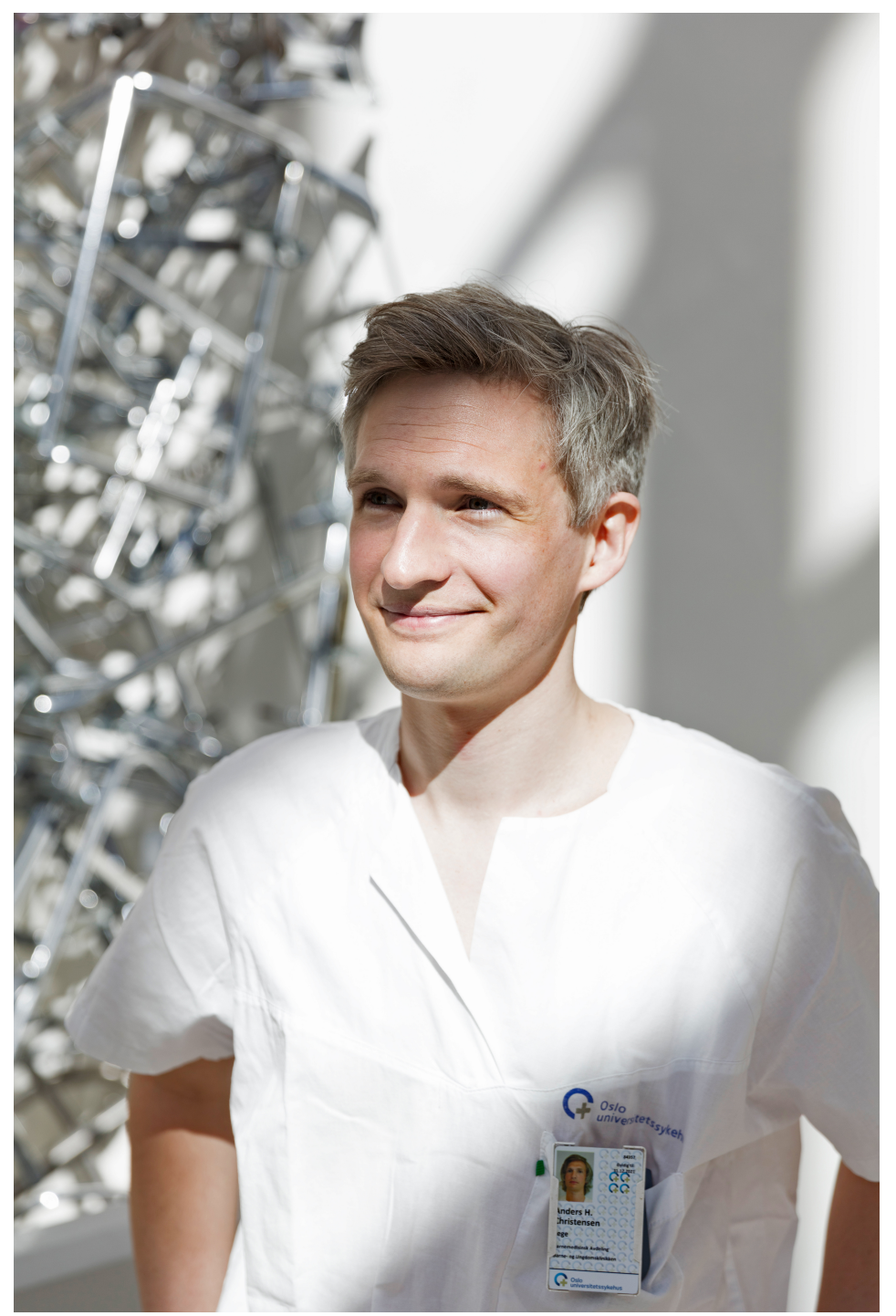

Foto: Christian Tunge

Han er opptatt av presisjon i diagnostikk og intervensjonell behandling av medfødte hjertefeil. I et fagfelt uten offisiell grenspesialisering, finnes det likevel noen muligheter for subspesialisering. For øvrig forsker han på reinnervasjon etter hjertetransplantasjon. 


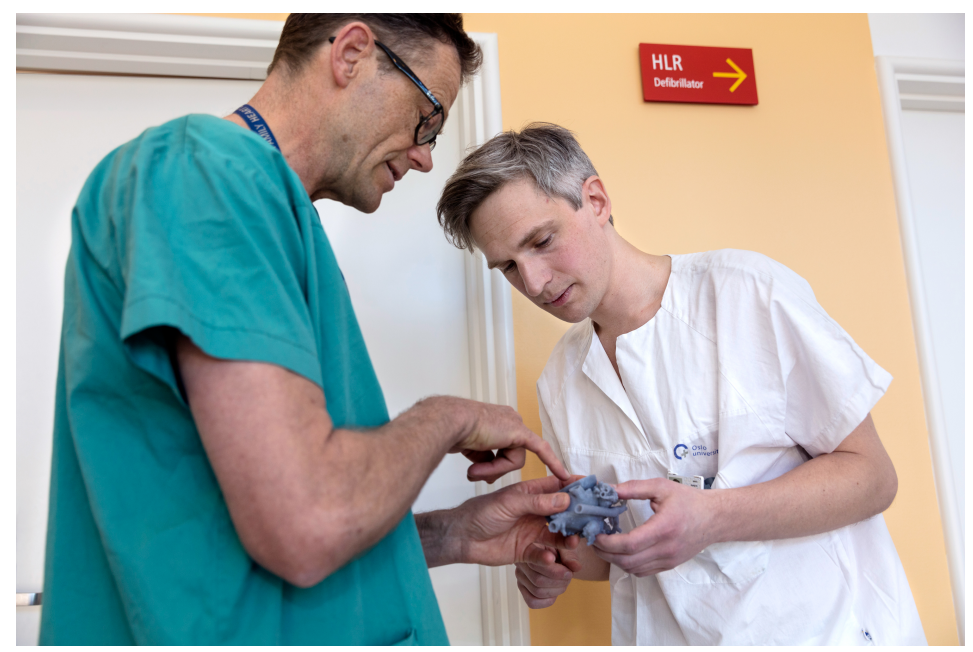

\section{Kan du fortelle om noe viktig som skjer i faget ditt for tiden?}

Å lykkes i behandlingen av barn med medfødte hjertefeil handler mye om planlegging. Forbedret intrauterin diagnostikk har gitt oss muligheten til å planlegge pasientforløp allerede prenatalt. En ny generasjon ultralydmaskiner gir oss anatomiske og hemodynamiske detaljer som tidligere var vanskelig tilgjengelige. CT og MR er essensielle supplementer og gir mulighet for 3D-printing av pasientens hjerte i faktisk størrelse. Slik kan kirurgene holde en modell i hendene og eventuelt øve på vanskelige operasjoner. Videre jobbes det med hologramløsninger som kan være med inn på operasjonsstuen som et tredimensjonalt kart. Det handler om å vite mest mulig preoperativt for å unngå ubehagelige overraskelser. Detaljert kartlegging setter oss i stand til å se nye angrepspunkter i behandlingen og oftere velge riktig modalitet. Et godt samarbeid med thoraxkirurgene gjør at pasientene får kirurgisk behandling som muliggjør senere intervensjonell oppfølging, og dermed reduseres antall nødvendige kirurgiske inngrep.

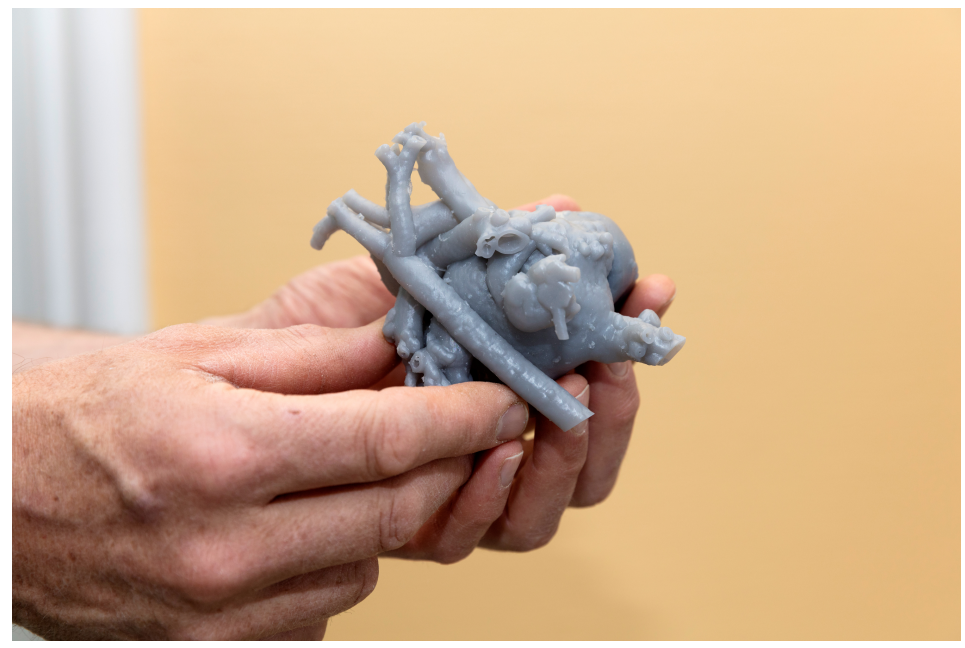

\section{Kan du anbefale en ny og interessant artikkel?}

I flere tiår har man vellykket lukket atrieseptumdefekter intervensjonelt. Etter stor initial optimisme viste det seg at intervensjonell lukking av perimembranøse ventrikkelseptumdefekter ga en uakseptabel risiko for utvikling av komplett AV-blokk. De siste årene er det blitt utviklet nytt, mer skånsomt utstyr. Tallene publisert fra et europeisk register (EUREVECO) viste ingen permanente tilfeller av komplett AV-blokk blant 81 pasienter med median oppfølgingstid på 31 måneder (1). Kanskje kan dette bli morgendagens behandling av denne vanlige hjertefeilen? 


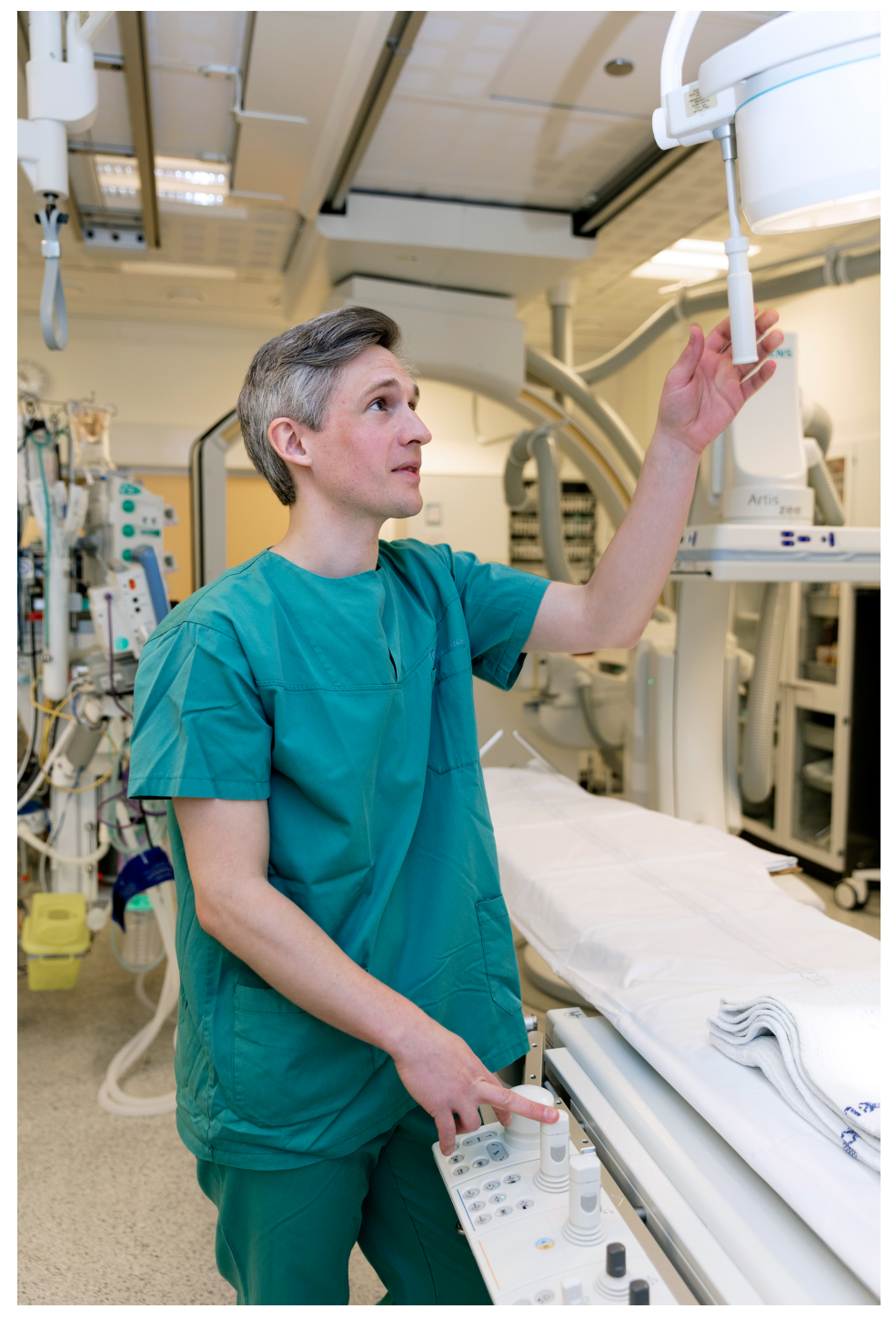

\section{Hva er ditt favoritthjelpemiddel på jobb?}

Å passe på små barn med tidvis komplekse hjertefeil er ofte krevende. Mitt viktigste hjelpemiddel er definitivt en fyldig telefonliste og vissheten om at dyktige kolleger fra barneanestesi, thoraxkirurgi, nyfødtmedisin og radiologi kun er minutter unna om situasjonen tilspisser seg. Ellers vil jeg anbefale Barnelegeforeningens akutt- og generellveileder i pediatri som svært nyttige hjelpemidler for alle som behandler barn.

\section{LITTERATUR:}

1. Haas NA, Kock L, Bertram H et al. Interventional VSD-Closure with the Nit-Occlud(®) Lê VSD-Coil in 110 Patients: Early and Midterm Results of the EUREVECO-Registry. Pediatr Cardiol 2017;38: 215 - 27. [PubMed][CrossRef]

Publisert: 21. august 2017. Tidsskr Nor Legeforen. DOI: 10.4045/tidsskr.17.039o (C) Tidsskrift for Den norske legeforening 2020. Lastet ned fra tidsskriftet.no 